\title{
Analysis of Oyster Mushroom Farming in Highlands (A Case Study in Sleman and Temanggung Indonesia)
}

\author{
Nur Rahmawati ${ }^{1, *}$ and Marbudi ${ }^{1}$ \\ ${ }^{1}$ Universitas Muhammadiyah Yogyakarta, Department of Agribusiness, 55183 Yogyakarta, Indonesia
}

\begin{abstract}
This study aims to discover the characteristics, cost, profit, and feasibility of oyster mushroom farming in highlands, specifically in Sleman and Temanggung Regency, Indonesia. Location determination was done purposively because the two regencies are in highlands. A snowball method was utilized to determine the respondents consisting of 32 oyster mushroom farmers. A descriptive method and t-test were employed to analyze the differences in the average cost, income, profit, and benefit-cost of farming. The results revealed that there were differences in the input and process technology characteristics of oyster mushroom farming in both regencies, leading to the differences in the profit and feasibility. However, there was no difference in the costs incurred between the two farming areas. The profit and feasibility of oyster mushroom farming in Temanggung were higher than those in Sleman. Nonetheless, the cost of farming in both regencies was relatively the same. Hence, it is necessary to increase the potential of oyster mushroom farmers in Sleman and strengthen the farmers in Temanggung so that the quality and productivity of oyster mushrooms in the two regencies can be stable and increase. Therefore, it will have an impact on the income and profit of farmers.
\end{abstract}

\section{Introduction}

\section{Us Introduction}

Agricultural development of the horticulture sub-sector is aimed at establishing food self-sufficiency, improving nutrition, and increasing community benefits [1]. As the population increases, human needs for horticultural commodities continue to rise. Mushrooms are one of the horticultural commodities having high nutritional content. They contain $19-35 \%$ protein, the nine essential amino acids, and $72 \%$ unsaturated fats [2].

Mushrooms will grow well in highlands due to their characteristics requiring a humid temperature. The ideal temperature for oyster mushroom farming is $22^{\circ}-28^{\circ} \mathrm{C}$, and humidity is around $60 \%-80 \%$. These temperature and humidity are typical in highlands. Thus, the oyster mushrooms will grow optimally in highlands [3].

Due to the excellent flavor, adequate-protein content, and quite high health values, mushrooms are unquestionably one of the most nutritious and tasty food sources relatively

\footnotetext{
*Corresponding author: rahma_wati_mf@umy.ac.id
} 
unexplored. Despite problems in farming, there is a possibility of using mushrooms in an essential role, being a source of protein to enrich human diets. Furthermore, they also have meditational values in these regions where the shortage of protein is highlighted. Out of more than 50 varieties of mushrooms consumed in India, only three of them button mushroom (Agaricus bosporus), oyster mushroom (Pleurotus spp.), and paddy straw mushroom are commercially cultivated. Moreover, among the three types of most cultivated mushrooms, the oyster mushroom is the easiest to cultivate at a low cost. [4]. The research result show that oyster mushroom flour increased the amino acid profile of the composite flour, with leucine being the highest [5]

All this time, oyster mushroom farming in Indonesia has only been concentrated in Java Island Specifically, the mushroom production centers in Java spread in four provinces: West Java, Central Java, Special Region of Yogyakarta (DIY), and East Java [6]. The widely-cultivated type of mushroom in both Sleman and Temanggung is the oyster mushrooms. In addition, mushroom production in the four provinces reaches $97 \%$ of total national production. Moreover, Central Java Province has the highest level of productivity; on the contrary, DIY has the lowest productivity level [7] even though it has a broader farming area compared to Central Java [8].

Sleman is the largest mushroom-producing regency in the DIY, while Temanggung Regency is the second-largest mushroom producer in Central Java Province after Semarang Regency. Although both are located in highlands, mushroom farming in Sleman and Temanggung have different productivity levels. Mushroom production in Sleman tends to decrease by $1.6 \%$ per year, whereas in Temanggung, it tends to increase by $59.2 \%$ per year [8]. The less optimal development of the potential of oyster mushroom farming in Sleman has caused a decline in production. On the other hand, the increase of mushroom production in Temanggung has led to the higher potential for developing oyster mushroom farming.

The difference in the productivity of oyster mushroom farming might be influenced by the differences in farming characteristics, later affecting the costs and benefits of farming. Besides, technology can primarily increase production capabilities and significantly reduce the cost of farming [9]. Additionally, mushroom houses area, mushroom seeds, wood powder, rice bran, lime, and labor affect the cost and benefit of oyster mushroom farming [10]. Furthermore, the use of labor affects the overall capital input, leading to saving in production costs or an increase in productivity [11].

The key to the success of oyster mushroom farming is affected by the ability to determine the number and combination of production factors. The right and efficient amount and combination of production factors will be able to reduce farming cost, making farmers obtain optimal production [10]. This study aims to determine the characteristics and analyze the feasibility of oyster mushroom farming in highlands. The results of the study are expected to be used as evaluation material for farmers to achieve better oyster mushroom farming in Indonesia.

\section{Research Method}

This study employed descriptive research methods and simple calculations. Data were collected through observation, interviews with questionnaire assistance, and field documentation. The number of sample populations in each district is not known with certainty. Therefore, the sampling method used is snowball sampling. Utilizing a snowball sampling, 32 oyster mushroom farmers were chosen as the respondents, consisting of 15 oyster mushroom farmers in Sleman and 17 farmers in Temanggung Regency. A simple calculation was done to find out the farming cost, profit, and benefit-cost ratio $(\mathrm{B} / \mathrm{C})$. The $\mathrm{t}-$ 
test was carried out to test hypotheses related to differences in the cost, profit, and $\mathrm{B} / \mathrm{C}$ of oyster mushroom farming in Sleman and Temanggung.

\section{Result and Discussion}

This study compares the characteristics of the management, farming analysis, and feasibility of oyster mushroom farming in Sleman and Temanggung.

\subsection{Characteristics of Oyster Mushroom Management}

Management of oyster mushroom farming in highlands of Sleman and Temanggung has different characteristics affecting the farming analysis and feasibility of the business. These characteristics cover the profile of oyster mushroom farmers and management technology, including technology from the input side, the side of the production process, and the output side.

\subsubsection{Profile of Oyster Mushroom Farmers}

The profile of farmers consists of age, education, the period of farming carried out, and the extent of the farming area of the oyster mushroom.

Table 1. Profile of Oyster Mushroom Farmers

\begin{tabular}{|c|c|c|c|c|}
\hline \multirow[b]{2}{*}{ Characteristic } & \multicolumn{2}{|c|}{ Sleman Regency } & \multicolumn{2}{|c|}{ Temanggung Regency } \\
\hline & $\begin{array}{c}\text { Number of } \\
\text { Farmers } \\
\text { (person) }\end{array}$ & $\begin{array}{c}\text { Percentage } \\
(\%)\end{array}$ & $\begin{array}{c}\text { Number of } \\
\text { Farmers } \\
\text { (person) }\end{array}$ & $\begin{array}{c}\text { Percentage } \\
(\%)\end{array}$ \\
\hline \multicolumn{5}{|l|}{ Age (years) } \\
\hline $20-42$ & 9 & 60 & 14 & 82 \\
\hline $43-64$ & 5 & 33 & 3 & 18 \\
\hline$>64$ & 1 & 7 & - & - \\
\hline Total & 15 & 100 & 17 & 100 \\
\hline \multicolumn{5}{|l|}{ Education } \\
\hline $\begin{array}{l}\text { Did not graduate from } \\
\text { elementary school }\end{array}$ & 1 & 7 & - & - \\
\hline Elementary School & 0 & - & 2 & 12 \\
\hline Junior High School & 1 & 7 & 5 & 29 \\
\hline Senior High School & 9 & 60 & 8 & 47 \\
\hline College & 4 & 26 & 2 & 12 \\
\hline Total & 15 & 100 & 17 & 100 \\
\hline \multicolumn{5}{|c|}{ Farming Experience (years) } \\
\hline $1-5$ & 4 & 27 & 12 & 70 \\
\hline $6-10$ & 5 & 33 & 2 & 12 \\
\hline$>10$ & 6 & 40 & 3 & 18 \\
\hline Total & 15 & 100 & 17 & 100 \\
\hline \multicolumn{5}{|l|}{ Area of the farm $\left(\mathrm{m}^{2}\right)$} \\
\hline$<250$ & 7 & 47 & 11 & 64 \\
\hline $251-500$ & 2 & 13 & 3 & 18 \\
\hline $500-750$ & 2 & 13 & 1 & 6 \\
\hline $750>$ & 4 & 27 & 2 & 12 \\
\hline Total & 15 & 100 & 17 & 100 \\
\hline
\end{tabular}


In terms of age, the oyster mushroom farmers in Temanggung (100\%) were more productive compared to farmers in Sleman (93\%). However, based on the level of education, the percentage of farmers in Sleman having a higher education level is greater than those in Temanggung. As seen in Table 1, 86\% of the oyster mushroom farmers in Sleman have a high level of education (senior high school and college). Still, only $59 \%$ of oyster mushroom farmers in Temanggung included in this category. Furthermore, in terms of experience, the majority of oyster mushroom farmers in Sleman were more experienced than those in Temanggung, indicated by $70 \%$ of farmers in Sleman having six years of experience, while in Temanggung only $30 \%$ of them have such experience.

There are two types of oyster mushroom farming places, kumbung, and production site. Kumbung is a building used for oyster mushroom farming, while the production site is a building used to prepare for planting the mushrooms. Small farmers are those having a kumbung area of $250-500 \mathrm{~m}^{2}$, whereas large farmers are those having a kumbung area of $750-1,000 \mathrm{~m}^{2}[12]$. Oyster mushroom business place in Temanggung having an area of fewer than $750 \mathrm{~m}^{2}$ reaches $88 \%$, while in Sleman, it only reaches $73 \%$. The average area of oyster mushroom farming in Temanggung and Sleman Regencies is $285 \mathrm{~m}^{2}$ and $973 \mathrm{~m}^{2}$, respectively, due to a farmer in Sleman having a business area of 9,000 $\mathrm{m}^{2}$.

\subsubsection{The Processing Technology of Oyster Mushroom Farming}

\subsubsection{The Technology of the input side}

Table 2. Input Technology of Oyster Mushroom Farming in Highlands

\begin{tabular}{|c|c|c|c|c|}
\hline \multirow[b]{2}{*}{ Description } & \multicolumn{2}{|c|}{ Sleman Regency } & \multicolumn{2}{|c|}{ Temanggung Regency } \\
\hline & $\begin{array}{c}\text { Number of } \\
\text { Farmers } \\
\text { (person) }\end{array}$ & $\begin{array}{c}\text { Percentage } \\
(\%)\end{array}$ & $\begin{array}{c}\text { Number of } \\
\text { Farmers } \\
\text { (person) }\end{array}$ & $\begin{array}{c}\text { Percentage } \\
(\%)\end{array}$ \\
\hline \multicolumn{5}{|l|}{ Amount of mushroom baglog } \\
\hline $1,000-5,000$ & 4 & 27 & 5 & 29 \\
\hline $5,000-20,000$ & 5 & 33 & 6 & 36 \\
\hline $20,000-50,000$ & 2 & 13 & 5 & 29 \\
\hline$>50,000$ & 4 & 27 & 1 & 6 \\
\hline Total & 15 & 100 & 17 & 100 \\
\hline \multicolumn{5}{|l|}{ Plastic baglog size $(\mathrm{cm})$} \\
\hline $18 \times 35$ & 1 & 7 & 10 & 59 \\
\hline $19 \times 35$ & 0 & - & 4 & 23 \\
\hline $20 \times 35$ & 14 & 93 & 3 & 18 \\
\hline Total & 15 & 100 & 17 & 100 \\
\hline \multicolumn{5}{|l|}{ Type of cover baglog } \\
\hline Rubber bracelet & 1 & 7 & 0 & - \\
\hline Baglog rings and paper & 3 & 20 & 12 & 70 \\
\hline Baglog rings and cotton & 11 & 73 & 5 & 30 \\
\hline Total & 15 & 100 & 17 & 100 \\
\hline \multicolumn{5}{|l|}{ Composition of baglog } \\
\hline Seeds (baglog / bottle) & \multicolumn{2}{|c|}{46} & \multicolumn{2}{|c|}{32} \\
\hline Bran (gram / baglog) & \multicolumn{2}{|c|}{91} & \multicolumn{2}{|c|}{104,5} \\
\hline Dolomite (gram / baglog) & \multicolumn{2}{|c|}{9,2} & \multicolumn{2}{|c|}{11,5} \\
\hline
\end{tabular}


When this research was conducted, farmers in Sleman cultivated around 35,233 baglogs, while in Temanggung, they merely planted around 21,735 baglogs. Both of these cultivation groups are included in medium-sized agriculture because they grow mushrooms with a total number of 20,000-50,000 baglogs [12].

Baglog plastic is one of the main inputs in oyster mushroom farming. Most farmers (98\%) in Sleman utilized large size plastic while in Temanggung, only $18 \%$ of them using the same plastic size. The bigger the plastic used, the bigger the baglog size is. Indeed, bigger baglog size generates higher production. However, a bigger baglog also has a higher risk of failure.

Seeds are one of the most influential inputs in cultivating oyster mushrooms. Excellent seeds will produce mycelium quickly, resulting in a higher potential mushroom growth. Moreover, the more seeds planted, the faster the spread of the mycelium will be. However, the seeds should be highly nourished by giving sufficient bran. Rice bran is a well-known source of nutrients needed for the growth of the seeds. The more bran given to the seeds, the higher the nutrients will be. In addition, lime will also support mushroom growth by increasing the acidity $(\mathrm{pH})$ of the oyster mushroom media. The right combination of seeds, bran, and dolomite has the potential to obtain maximum results. Besides, the most crucial prerequisite for successful mushroom production is a high-quality compost substrate [13]

Based on Table 2, the nutritional content of each baglog of oyster mushrooms in Temanggung was higher than that in Sleman. Likewise, the number of seeds in Temanggung in which each bottle of seed was used for 32 baglogs, while in Sleman it was applied for 46 baglogs. Hence, it affected the production of oyster mushrooms.

Baglog cover is an input used to protect its front surface from water, insects, and several things that can interfere with the growth of oyster mushroom mycelium. A good baglog cover will accelerate the growth of mushroom mycelium, thereby increasing the success of mushroom production.

\subsubsection{The Technology of Process side}

The technology of the process will affect the production of oyster mushrooms. Technologies used during the process are pre-production sawdust storage, storage, pasteurization, inoculation, incubation, air circulation, and watering.

The storage place for raw materials is an essential factor in making mushroom baglog. Meanwhile, sawdust is the primary raw material used as a media for growing oyster mushrooms due to its high amino acid content [14]. Therefore, proper treatment is required to optimize the growth of mushrooms. Sawdust should avoid rainwater, insects, and beetle larvae as they can cause damage. Half of the oyster mushroom farmers in Sleman stored the sawdust in open areas before processing, while $88 \%$ of farmers in Temanggung stored their sawdust in roofed places in sacks.

The storage process is the procedure of inserting media into baglog plastic carried out manually and automatically. The next process was refilling and then followed by pressing performed manually, semi-automatically, and automatically. The majority of the oyster mushroom farmers $(87 \%)$ in Sleman chose to do it automatically, while only $30 \%$ of farmers in Temanggung used semi-automatic and automatic press tools. The denser the baglog, the higher the potential obtained due to the volume of baglog.

Pasteurization is the process of eradicating pathogens by utilizing hot steam. It is influential in the sustainability of the growth of mushroom mycelium. Pasteurization technology also determines the sterilization of planting media that will affect productivity [15]. The pasteurization process carried out by $87 \%$ of farmers in Sleman utilizing heating space. However, in Temanggung, they tended to employ drums to pasteurize. 
Incubation is a baglog storage process having been inoculated to a white baglog. Oyster mushroom incubation requires a closed place to protect the baglog from other fungi that can cause contamination. The baglog incubation process was carried out for 30-50 days after the inoculation process. Furthermore, it should be carried out at temperatures ranging from $22-28{ }^{\circ} \mathrm{C}$ with humidity of $70-90 \%$ to assist the growth of mushroom mycelium [15]. Successful incubation will produce an even white color baglog. In general, the incubation space used by farmers in Temanggung was a special and closed room. It allowed the incubation process to run well, resulting in a good quality baglog. As for the incubation process in Sleman, almost half of the farmers used makeshift and open space, causing the abnormal growth of mycelium due to the hot condition of the baglog.

Table 3. Technology Process of Oyster Mushroom Farming in Highlands

\begin{tabular}{|c|c|c|c|c|}
\hline \multirow[b]{2}{*}{ Treatment } & \multicolumn{2}{|c|}{ Sleman Regency } & \multicolumn{2}{|c|}{ Temanggung Regency } \\
\hline & $\begin{array}{l}\text { Number of } \\
\text { Farmers } \\
\text { (person) }\end{array}$ & $\begin{array}{c}\text { Percentage } \\
(\%)\end{array}$ & $\begin{array}{l}\text { Number of } \\
\text { Farmers } \\
\text { (person) }\end{array}$ & $\begin{array}{c}\text { Percentage } \\
(\%)\end{array}$ \\
\hline \multicolumn{5}{|l|}{ Sawdust storage area } \\
\hline Open space & 7 & 47 & 2 & 12 \\
\hline Roofed & 8 & 53 & 15 & 88 \\
\hline Total & 15 & 100 & 17 & 100 \\
\hline \multicolumn{5}{|l|}{ Type of cover } \\
\hline Manual & 2 & 13 & 12 & 70 \\
\hline Semi-Automatic & 12 & 80 & 4 & 24 \\
\hline Automatic & 1 & 7 & 1 & 6 \\
\hline Total & 15 & 100 & 17 & 100 \\
\hline \multicolumn{5}{|c|}{ Type of pasteurization tool } \\
\hline Heating room & 13 & 87 & 4 & 23 \\
\hline Drum & 2 & 13 & 13 & 77 \\
\hline Total & 15 & 100 & 17 & 100 \\
\hline \multicolumn{5}{|l|}{ Place of Inoculation } \\
\hline Special and closed & 11 & 73 & 16 & 94 \\
\hline Random and open & 4 & 27 & 1 & 6 \\
\hline Total & 15 & 100 & 17 & 100 \\
\hline \multicolumn{5}{|l|}{ Incubation Place } \\
\hline Special and closed & 8 & 53 & 16 & 94 \\
\hline Random and open & 7 & 47 & 1 & 6 \\
\hline Total & 15 & 100 & 17 & 100 \\
\hline \multicolumn{5}{|l|}{ Air circulation } \\
\hline Special and closed & 8 & 53 & 16 & 94 \\
\hline Sober and open & 7 & 47 & 1 & 6 \\
\hline Total & 15 & 100 & 17 & 100 \\
\hline \multicolumn{5}{|l|}{ Watering process } \\
\hline Spraying water & 6 & 40 & 13 & 76 \\
\hline Non spraying water & 9 & 60 & 4 & 24 \\
\hline Total & 15 & 100 & 17 & 100 \\
\hline
\end{tabular}

Air circulation in the kumbung, used as a place for the farming of oyster mushrooms, should have sufficient air circulation. Poor air circulation might inhibit the growth process of oyster mushrooms. In general, the kumbung used in the two regencies were made of bamboo walls, providing sufficient air circulation. However, there were two kumbung in Sleman made of brick. Nonetheless, both kumbung were in an open space and had sufficient ventilation. 
Inoculation is the process of planting oyster mushroom seeds in baglog requiring a closed and sterile place. In general, farmers in both regencies had fulfilled the requirement of conducting inoculation. However, the number of farmers in Temanggung carrying out inoculation in special and closed spaces was higher compared to those in Sleman. In short, such a way of inoculation has the potential to produce a better baglog with a low level of contamination.

There are two types of a watering process carried out by farmers, a fog system and nonfog. The method of watering the mouth of baglog using the non-fog procedure allows the excess water in baglog, resulting in the high moisture in the baglog mouth. However, too high humidity causes the oyster mushroom to have excess water content, making them more fragile and rotten [3].

\subsubsection{The Technology of the output side}

The technology of the output side of oyster mushroom farming is a post-harvest technique. Almost all oyster mushrooms produced by farmers in both regencies were sold fresh.

Table 4. Output Technology of Oyster Mushroom Farming in Highlands

\begin{tabular}{|l|c|c|c|c|c|c|c|c|}
\hline \multirow{3}{*}{ Treatment } & \multicolumn{4}{|c|}{ Sleman Regency } & \multicolumn{4}{c|}{ Temanggung Regency } \\
\cline { 2 - 9 } & $\begin{array}{c}\text { Yes } \\
\text { (person) }\end{array}$ & $\%$ & $\begin{array}{c}\text { No } \\
\text { (person) }\end{array}$ & $\%$ & $\begin{array}{c}\text { Yes } \\
\text { (person) }\end{array}$ & $\begin{array}{c}\text { No } \\
\text { (person) }\end{array}$ & $\%$ \\
\hline Sorting & 15 & 100 & - & - & 17 & 100 & - & - \\
\hline Grading & 6 & 40 & 9 & 60 & - & - & 17 & 100 \\
\hline
\end{tabular}

As presented in Table 34the output technology comprises two activities, sorting and grading. Before selling the oyster mushrooms to intermediaries, farmers in both regencies sorted them. However, the grading was only done by $40 \%$ of oyster mushroom farmers in Sleman since it was carried out based on buyers' requests. Although oyster mushroom farmers in Temanggung district do not do grading, the selling price is the same as the grading

\subsection{Analysis of Oyster Mushroom Farming}

The farming analysis conducted on 28,000 baglogs in one oyster mushroom farming season aims to determine the use of fixed and variable costs, production costs, profit, and feasibility of oyster mushroom farming in highlands. One oyster mushroom farming season lasted for four months.

The total fixed cost of oyster mushroom farming in Sleman, reached IDR 4,256,502, was two times greater than in Temanggung, spending only IDR 2,179,208. Fixed costs consist of depreciation and equipment costs. Depreciation costs for kumbung in Sleman were also higher than that in Temanggung. However, these costs were lower than those in Jember Regency for an area of $19 \mathrm{~m}^{2}$ with a capacity of 975 baglogs for one period in 2014; it spent IDR 327,898 [16] Depreciation costs of the same size $\left(19 \mathrm{~m}^{2}\right)$ were around IDR 168,620 in Sleman and IDR 101,719 in Temanggung.

The total variable costs of oyster mushroom farming in Sleman was lower than in Temanggung. In addition, the most significant cost incurred in Temanggung was on labor, considering it is the most crucial variable in the management of oyster mushrooms farming. Additionally, this workforce consisted of workers from the family and outside the family. Moreover, the purchase cost of the bran was the highest cost of labor, as it was an essential input used as a source of the mushroom nutrients. Farmers in Temanggung used more bran, 105 grams per baglog, while in Sleman, they only used 91 grams per baglog. 
Actually,farmers can potentially reduce the cost of rice bran by replacing the rice bran with cassava pells as mushroom nutrition. Certain agricultural waste that can be used in addition to rice bran are wheat bran and palm kernel cake (PKC) which are both high in nitrogen. The use of cassava peels in the production of spawn for the cultivation of edible mushrooms would reduce the production costs of mushroom farmers, as the costs of buying spawned sorghum grains have been assessed by the farmers as being high, The market price of cassava peels is relatively lower than that of sorghum grains. This will inevitably raise the profit margin of mushroom farmers and inspire more people to take up mushroom farming business [17]

Table 5. Analysis of Oyster Mushroom Farming in Highlands per 28,000 baglogs

\begin{tabular}{|l|r|r|}
\hline Component of Cost & $\begin{array}{c}\text { Sleman Regency } \\
\text { (IDR) }\end{array}$ & $\begin{array}{c}\text { Temanggung Regency } \\
\text { (IDR) }\end{array}$ \\
\hline Fixed cost & & 993,472 \\
\hline 1. Rent land & $1,141,868$ & $1,525,793$ \\
\hline 2. Depreciation of kumbung & $2,529,309$ & 369,169 \\
\hline 3. Depreciation of tools & 578,537 & 7,451 \\
\hline 4. Land and building tax & 6,778 & $2,879,208$ \\
\hline Total fixed costs & $4,256,502$ & $5,440,136$ \\
\hline Variable Costs & & $8,792,905$ \\
\hline 1. Sawdust & $5,946,009$ & 258,835 \\
\hline 2. Rice bran & $6,797,665$ & $4,797,664$ \\
\hline 3. Lime & 200,165 & 465,898 \\
\hline 4. Plastic & $5,493,600$ & $4,134,180$ \\
\hline 5. Cover baglog & 389,939 & $2,833,806$ \\
\hline 6. Seeds & $3,233,925$ & $9,691,763$ \\
\hline 7. Fuel & $3,131,085$ & 201,954 \\
\hline 8. Labor & $9,611,388$ & $36,619,201$ \\
\hline 9. Other costs & 359,488 & 10,105 \\
\hline Total variable costs & $35,163,263$ & 8,985 \\
\hline Total Cost & $39,419,765$ & $90,789,795$ \\
\hline Production $(\mathrm{kg})$ & 7,946 & $51,291,386$ \\
\hline Selling price (IDR / $\mathrm{kg})$ & 10,326 & 1.30 \\
\hline Reception & $82,052,616$ & \\
\hline Profit & $42,632,853$ & 1.08 \\
\hline Benefit-Cost Ratio (B/C) & & \\
\hline
\end{tabular}

The plastic costs for oyster mushroom farming in Sleman was higher than that in Temanggung due to the bigger size of plastic used. Nonetheless, the costs of the seeds in Temanggung as higher than those in Sleman due to the more amount of seeds used. In brief, the total costs incurred for oyster mushroom farming in Sleman and Temanggung were almost similar. Statistically, the results are not significant, with a 5\% error rate, meaning that there were no differences in costs between the oyster mushroom farmings in the two highland areas.

Oyster mushroom production in Sleman for one planting season was only 7,946 kilograms. However, the selling price reached IDR 10,300 per kilogram. While the production in Temanggung reached 10,105 kilograms with a selling price of only IDR 9,000 per kilogram, that it received revenues of IDR 90,789,794.

In terms of profit, oyster mushroom farmers in Temanggung obtained higher profit than those in Sleman. With a total cost of IDR 39,419,765, farmers in Sleman only received a profit of IDR 42,632,853 per planting season. Meanwhile, in Temanggung, they were able to generate a profit of IDR 51,291,386 per planting season with a total cost of IDR $39,798,409$. These results are reinforced by the t-test showing a significant error rate of 
$15 \%$. It indicates a difference in the profit of oyster mushroom farming in both regencies due to the different management processes, particularly in terms of input, process, and output.

Benefit-cost ratio $(\mathrm{B} / \mathrm{C})$ is a measure of feasibility calculated by comparing profit for one production period with total production costs [18]. The value of $\mathrm{B} / \mathrm{C}$ of oyster mushroom farming in Sleman was 1.08, while in Temanggung, it reached 1.34. It means that every IDR 1 invested in oyster mushroom farming in Sleman generated a profit of IDR 1.08, while in Temanggung it received a profit of IDR 1.34. The difference in eligibility is strengthened statistically by the t-test, significant at an error rate of $16 \%$. However, the value of $\mathrm{B} / \mathrm{C} \#$

as still lower than that of oyster mushroom farming in Simpang Baru Village, Tampan District, and Pekanbaru City, which could reach 2.04 in one production process [19]. The low value of $\mathrm{B} / \mathrm{C}$ in this study was caused by various challenges related to lack of space for production, baglog quality, mushroom diseases, and marketing of oyster mushrooms.

Moreover, significant challenges in the production of mushrooms in urban and periurban areas in Zimbabwe covers marketing problems, lack of space for production, quality of spawns and substrates, temperature control, mushroom diseases and water shortages [20]. Furthermore, the financial analysis of mushroom farming in $15 \times 6 \mathrm{~m}^{2}$ bamboo showed a $\mathrm{B} / \mathrm{C}$ ratio of 2.24. Despite the quite-good potentiality of this sector, Bangladesh is still left behind due to lack of popularity, labeling, attractive packaging, and spawn packets for seeding [21].

Most oyster mushroom farming studies are feasible, such as in Sleman Regency [22], in Lampung Province [23], and Metro Lampung City [23].

\section{Conclusions}

In a nutshell, the characteristics of the application of input and process technology for oyster mushroom farming in Temanggung were better than those in Sleman. In terms of cost, they had relatively the same spending. However, the profit earned by the two farmings was different, in which farmers in Temanggung obtained higher profit than those in Sleman. Oyster mushroom farming in highlands, according to the benefit-cost $(B / C)$ analysis, is profitable. The $\mathrm{B} / \mathrm{C}$ value of oyster mushroom farming in Temanggung was higher than that in Sleman.

It is necessary to improve the management of oyster mushrooms, specifically in terms of input, process, and output for farmers in Sleman and to improve the market structure for farmers in Temanggung to earn higher profit.

\section{References}

1. UU No. 13 Tahun 2010, Undang-Undang Hortikultura No.13 Tahun 2010 (2010).

2. N. Widyastuti, D. Tjokrokusumo, and R. Giarni, in Semin. Agroindustri Dan Lokakarya Nas. FKPT-TPI Progr. Stud. TIP-UTM, (2016), pp. 2-3.

3. L. Y. Adhiyana, S. Supardi, and R. A. Qonita, Agrista 4, 450 (2016).

4. R. Shukla and A. Tomar, Pharma Innov. J. 7, 856 (2018).

5. O. P. Bamidele and B. M. Fasogbon, Open Agric. 5, 40 (2020).

6. Badan Pusat Statistik, Statistik Tanaman Sayuran Dan Buah-Buahan Semusim Tahun 2014 (2015).

7. Badan Pusat Statistik, Statistik Tanaman Sayuran Dan Buah-Buahan Semusim Tahun 2016 (Badan Pusat Statistik, 2017). 
8. Badan Pusat Statistik, Statistik Tanaman Sayuran Dan Buah-Buahan Semusim Indonesia 2015 (2016).

9. Y. Zhang, W. Geng, Y. Shen, Y. Wang, and Y. Dai, 2961 (2014).

10. V. D. Puspitasari, E. Prasetyo, and H. Setiyawan, AgriSocionomics 1, 63 (2017).

11. R. M. Wardani, Agri-Tek 12, 69 (2011).

12. E. Djuwendah and E. Septiarini, Paspalum J. Ilm. Pertan. 4, 11 (2017).

13. T. Demirer, B. Röck-Okuyucu, and I. Özer, J. Agric. Rural Dev. Trop. Subtrop. 106, 71 (2005).

14. M. Yamauchi, M. Sakamoto, M. Yamada, H. Hara, S. Mat Taib, S. Rezania, M. D. Mohd Fadhil, and F. H. Mohd Hanafi, J. King Saud Univ. - Sci. 0 (2018).

15. E. Djuwendah and E. Septiarini, Paspalum1. Djuwendah E, Septiarini E. Manaj. Risiko Usahatani Jamur Tiram Putih ( Plerotus Astreotus ) Dalam Upaya Mempertahankan Pendapatan Petani. Paspalum. 2016;IV11-22. IV, 11 (2016).

16. A. S. Saputra, T. D. Hapsari, and J. Januar, Agritrop Junal Ilmu Ilmu Pertan. 13, 195 (2016).

17. A. O. Akinrinola-Akinyemi, A. E. Asagbra, W. B. Asiru, M. O. Lalemi, V. O. Okere, O. F. Oluwawole, O. M. Ajao, I. O. Isa, L. O. Sanni, E. N. Dike, and G. N. Elemo, Open Agric. 2, 250 (2017).

18. N. Hariadi, L. Setyobudi, and E. Nihayati, J. Produksi Tanam. 1, 47 (2013).

19. R. D. Shintia and Amalia, J. Ilmu-Ilmu Pertan. 13, 38 (2017).

20. M. Mutema, K. Basira, D. Savadye, and W. Parawira, Tanzania J. Sci. 45, 114 (2019).

21. M. N. Easin, R. Ahmed, M. S. Alam, M. S. Reza, and K. U. Ahmed, Int. J. Agric. For. Fish. 5, 1 (2017).

22. K. U. Rini Anggraenir, Subeni', Agro UPY IV, 1 (2012).

23. R. Candra, D. A. Hepiana L, and S. Situmorang, JIIA 2, 38 (2014). 